\title{
LOCATION CHOICE OF FOREIGN DIRECT INVESTMENT BY MULTINATIONAL CORPORATIONS FROM EMERGING COUNTRIES
}

Traditional discussion regarding multinational corporations (MNC) generally assumes that only firms possessing certain distinguishing advantages can successfully operate abroad. This paper examines the issue of emerging multinational corporations (EMNC), which do not represent high-end technology or excellent products, although they have become important international players in their industries. Moreover, numerous EMNCs have been capable of acquiring their established competitors in foreign countries. The main goal of the paper was to investigate the motives of selecting particular locations of foreign direct investment by "new" multinationals from four largest emerging economies (Brazil, the Russian Federation, India and China). The method applied to investigate the research problem was a multiple linear regression. The econometric analysis was enhanced by some selected facts about the EMNCs.

Keywords: international investment, multinational firms, mergers, acquisitions

JEL Classifications: F21, F23, G3

DOI: $10.15611 /$ aoe.2016.2.07

\section{INTRODUCTION}

The rise of outward foreign direct investment (FDI) from emerging countries embodies a clear indicator of changes in the global economy. The largest newly industrialised economies changed their status from being only recipients of capital in the form of FDI to becoming its important sources. We can label this change as going from passive to active participation in the flows of FDI. However, not all emerging economies faced similar surge of outflows (Figure 1). China and the Russian Federation stand out here and in just a few years reached levels equal to large advanced economies, like Japan and Germany. This expansion also brings implications for target countries. As FDI is a desirable form of capital in most economies, the determinants of selecting a particular destination by multinational corporations (MNC) from emerging countries should be identified. In the case of Brazil, the negative value observed in 2009 and 2011 is the result of large divestment projects by a mining firm.

\footnotetext{
* Department of International Economics, Wrocław University of Economics
} 


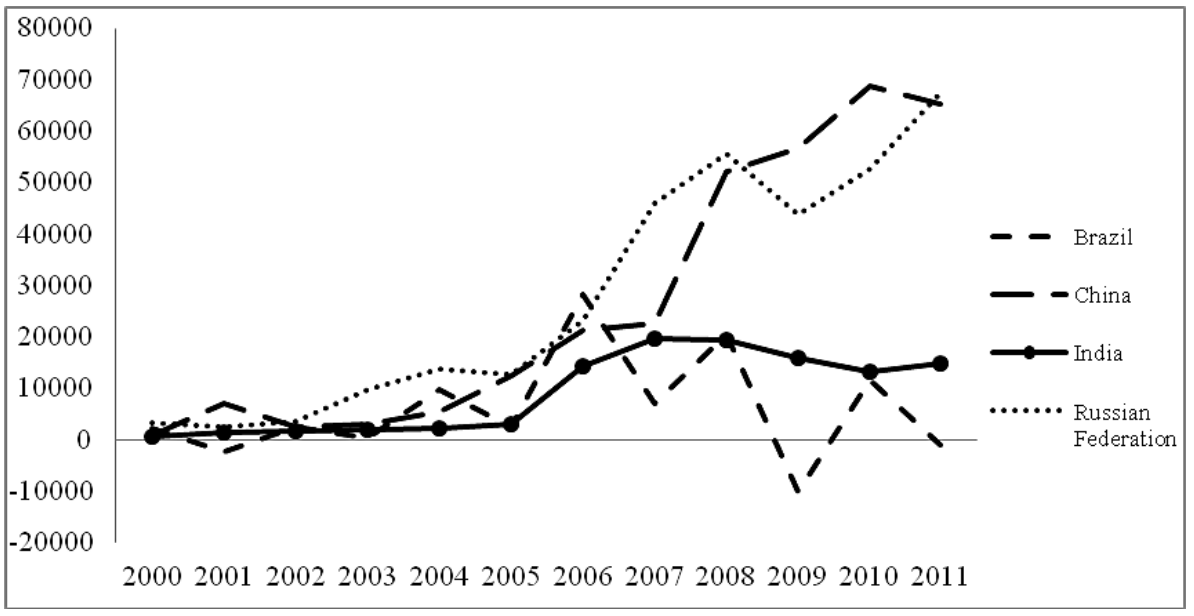

Note: BRIC - Brazil, Russian Federation, India, China

Figure 1. Outward foreign direct investment by the BRIC countries (2000-2011, USD m) Source: own calculation based on UNCTAD

Two basic entry modes of foreign direct investment are generally recognised: greenfield and cross-border mergers and acquisitions (M\&A). A greenfield project means establishing a new enterprise in the country of expansion, whilst the latter mode denotes the purchase of an existing business in a foreign country. There are different rationales supporting the decision to create or buy. Moreover, there are many differences in the characteristics of firms undertaking each type of investment projects (Klimek 2011).

Acquiring an existing firm in a foreign country has been the most prevailing form of FDI. The bulk of FDI between 2000 and 2008 took the form of cross-border mergers and acquisitions (UNCTAD, 2009). Therefore it is assumed that M\&A deals can be used as a proxy for the total activities of firms in the field of foreign investment.

The issue of M\&A by multinational enterprises from emerging countries is a distinctive phenomenon. First of all, business entities from emerging countries did not have enough capabilities to attain the requisite knowledge and state-of-the-art technology by themselves. Therefore, acquiring a firm that possesses these valuable intangible assets is sometimes the only viable option for further development. Additionally, firms from emerging countries are latecomers to international business and most of the crucial market 
niches have already been exploited by established competitors from advanced economies. In such cases M\&A also seems a more profitable opportunity, as the acquirer instantly has access to a foreign market.

Together with the question of entry mode comes the issue of optimal location selection for foreign expansion. In this respect, the further distinctive characteristics of EMNCs have already been recognised, for example the influence of a government on strategic decisions or the lack of capabilities to enter markets of intensive competition. These differences should also influence the choice of the host market.

The main aim of this paper is to analyse the pattern of country selection by multinational corporations from emerging countries in their foreign expansion. The key hypothesis is that favourable geographic conditions in target countries increase the inflow of FDI from emerging countries. A key research question is what attracts EMNCs to particular host economies? To find the answer, the multiple linear regression using data concerning the BRIC countries will be employed. The countries were chosen because they are the largest emerging economies and firms headquartered there represent a unique pattern of foreign expansion.

The econometric analysis will be preceded by some selected facts describing the population of EMNCs. It will include the cross-sectional analysis of industries, deal values and timeline of the transactions.

The remainder of the paper is organised as follows. Section 2 delivers a review of previous contributions in the field of location choice of MNCs; Section 3 contains the opening analysis of expansion of EMNCs from selected countries; Section 4 describes the econometric estimation procedure; Section 5 contains the results of the analysis and post-estimation tests; and Section 6 delivers the concluding remarks.

\section{THEORETICAL BACKGROUND}

This section will be devoted to a review of earlier contributions regarding both multinationals from advanced economies and firms from newly industrialised countries. In fact most of the previous works focused mostly on developed countries, hence there are only a few contributions regarding the location choice of firms from emerging economies.

The literature review will explore contributions in the field of international economics (IE) and international business (IB). The discussion about the location choice is more prevalent in the international business literature. However, an additional aim of this paper is to bring together these two perspectives. 
Many empirical contributions examined various factors that influenced FDI inflows in any form. The location decision was also an important element of Dunning's seminal contribution to explaining the international operations of multinational corporations (Dunning 1998). One of the most important determinants is the size of the host economy measured as the value of gross domestic product (GDP). Not only does the total measure of the economy matter, but also the size of the regions within the countries (Cheng et al. 2000). Moreover, IB literature confirms the rising relevance of market capacity in the expansion decision of firms from developed countries (Flores et al. 2007).

A commonly analysed factor influencing the location of FDI is the distance between the home and host countries. This is also a part of the gravity model that is frequently used to explain the size of trade flows between countries (Rivera-Batiz et al. 2003). The main idea of the model is that the volume of trade is positively related to the size of the economies of the trading partners and negatively related to the distance between them.

Distance can play various roles in the decision making about foreign engagement. Even if the use of modern communication techniques seemed to reduce the cost of cooperation in long distances, the issue of remoteness is still crucial in obtaining control over offshore firms. In a broader sense, the distance is also a proxy for information asymmetry (Ragozzino 2009). The significant size of information asymmetry can lead to partial-ownership solutions (e.g. joint venture) instead of full ownership (Reuer et al. 2000).

One more essential issue to highlight is the notion of a regional multinational corporation. This is associated with the fact that most multinationals engage primarily in countries of the region/continent of origin (Rugman 2005). MNCs are rarely global enterprises. The author of this paper assumes that multinational firms from emerging countries are more prone to maintain their regional character due to their limited managerial experience and other resources. Concentrating on the home region may be particularly beneficial when the neighbourhood consists of intensively growing economies, thus creating attractive markets.

Firms may be attracted to a particular location because of positive externalities that are described as agglomeration effects (Head et al. 1996). This means that firms prefer to invest in locations where their peers from the same country already operate. This geographic factor is important both at country and industry level. The importance of agglomeration should be considered together with integration processes. Empirical contributions suggest that in the case of the European Union, economic integration can moderate the agglomeration process in the core regions (Basile et al. 2008). 
The new wave of empirical contributions identifies the characteristics of firms as the key factor influencing decisions about engagement in any foreign location (Grossman et al. 2006). Such a trend seems to be justified by heterogeneity among firms, however there are also general rules governing economic relations between economies. The focus will be put on macro level characteristics that can influence foreign expansion. The firmlevel data in the analytic work will be utilized, nevertheless the main focus is on the characteristics of target locations.

\section{SELECTED FACTS}

Before proceeding to the econometric analysis, a brief data overview and some selected facts about the activities of firms from the four countries in the field of cross-border mergers and acquisitions are to be presented.

The main source of data on cross-border mergers and acquisitions was the DealWatch database provided by ISI Emerging Markets. The database, among other details, contains information about participating firms' names, countries of origin, values of deals and stakes in target companies.

Firms from the mentioned countries are rather newcomers in the field of acquiring existing firms abroad. In this part of analysis the period between 2003 and 2010 was covered. Nonetheless, some deals were also completed before 2003, but their number and value were not highly significant. The number of deals in the analysed period was the highest in times of prosperity both in the emerging countries and the entire world economy. The relationship between the global economic situation and foreign expansion of firms from the BRIC was considerable (Klimek 2012). 2007 and 2008 were particularly busy for firms looking for international purchases.

The main advantage of the analysis using the number of cross-border M\&A deals is that such data are unbiased by the market valuation of firms. The values of stock indices of major stock exchanges were highest in 2007, just before the crash of the US housing market. In 2009 and 2010, the number of M\&A deals by firms from the BRIC countries plummeted, affected by the collapse of the world financial system. However, many firms were flush with cash on their balance sheets. This created favourable conditions for foreign acquisitions, as the valuations of target firms dropped and many of them faced severe financial difficulties.

The analysis of the stakes in the acquired enterprises confirms that the purchases were predominantly of a majority type (Figure 2). In most cases the goal of the buyers was to embrace a controlling stake in the newly 
acquired firms. The rationale behind such commitment was the need to control strategic assets and future plans regarding the acquired firms. In all periods, firms from India were particularly focused on possessing larger stakes in foreign enterprises. In the analysed years, mean values for Indian firms were around $80 \%$ compared to around $60 \%$ in the case of Russian firms. Nonetheless, the desire to control entirely the acquired companies has been diminishing in recent years.

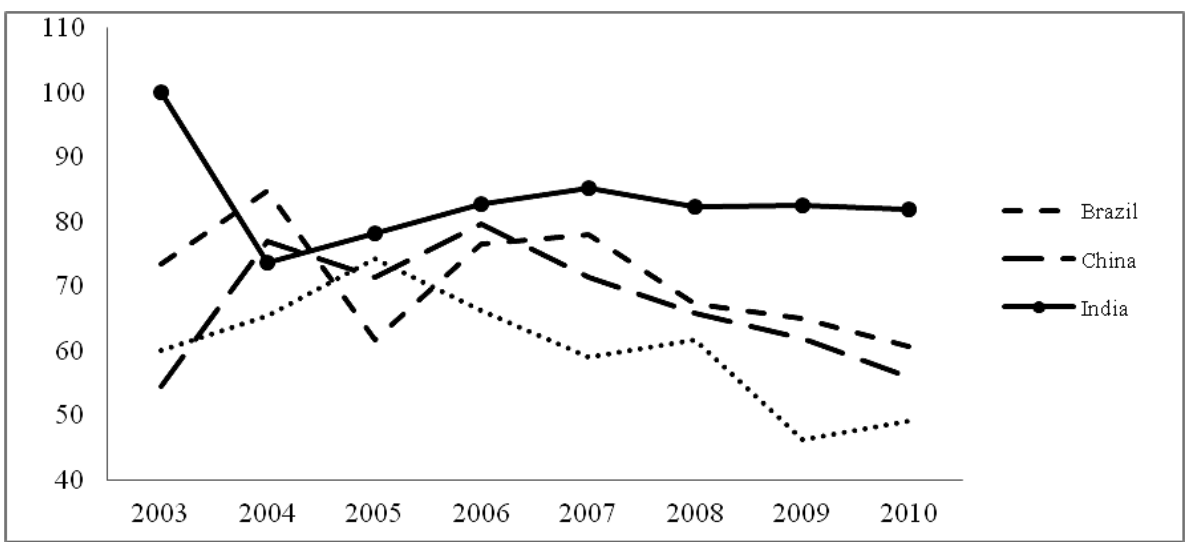

Figure 2. Stake in target enterprises by home countries (2003-2010)

Source: own calculation based on DealWatch

The opening study portraying the country and industry pattern was designed to define the appropriate explanatory variables for the econometric analysis in the following sections.

Firms from the BRIC countries represent a diverse set of destinations and activities in their foreign expansion. In the case of Brazil, the expansion of MNCs is agglomerated in neighbouring countries, which confirms the regional type of expanding firms. When analysing industries across the main recipient economies, it can be concluded that the highest numbers of deals are in industries associated with the abundance of natural resources (Table 1). ${ }^{1}$ Various types of mining companies are accompanied by the food industry. Brazil, as the

\footnotetext{
${ }^{1}$ Tables 1-4 present five economies with the largest number of investment project by firms from respective source countries. Among each target country up to four main industries were included. Values of the deals were added to present the complexity of the analysis of crossborder mergers and acquisitions by EMNEs. In some cases the industries with the highest number of transactions are accompanied by unrevealed values of those deals.
} 
largest exporter of beef and an important producer of other food products, is also a good place to start foreign expansion. Millions of hectares of farmland provide favourable conditions for developing this kind of business.

Table 1

Cross-border M\&A deals by the key countries and industries (Brazil)

\begin{tabular}{l|c|c|c|c}
\hline Target countries and industries (NAICS 2007) & $\begin{array}{c}\text { Total } \\
\text { number }\end{array}$ & $\begin{array}{c}\text { By } \\
\text { industry }\end{array}$ & $\begin{array}{c}\text { Total } \\
\text { value } \\
\text { (USD m) }\end{array}$ & $\begin{array}{c}\text { By } \\
\text { industry } \\
\text { (USD m) }\end{array}$ \\
\hline Argentina & 61 & & 6734.38 & \\
\hline Food Manufacturing (311) & & 10 & & 512.30 \\
\hline Leather and Allied Product Manufacturing (316) & & 7 & & 122.31 \\
\hline Primary Metal Manufacturing (331) & & 7 & & 227.40 \\
\hline Colombia & 22 & & 1644.19 & \\
\hline Primary Metal Manufacturing (331) & & 6 & & 758.36 \\
\hline Mining (except Oil and Gas) (212) & & 5 & & 446.83 \\
\hline Air Transportation (481) & & 3 & & 387.00 \\
\hline Uruguay & 20 & & 671.92 & \\
\hline Food Manufacturing (311) & & 6 & & 380.53 \\
\hline Oil and Gas Extraction (211) & & 2 & & 3.20 \\
\hline Gasoline Stations (447) & 18 & & 9187.03 & \\
\hline United States & & 3 & & 826.00 \\
\hline Oil and Gas Extraction (211) & & & & \\
\hline $\begin{array}{l}\text { Professional, Scientific, and Technical } \\
\text { Services (541) }\end{array}$ & & 3 & & 2048.87 \\
\hline Food Manufacturing (311) & 15 & & 855.72 & \\
\hline Mexico & & 4 & & 11.00 \\
\hline Chemical Manufacturing (325) & & 2 & & 26.70 \\
\hline Transportation Equipment Manufacturing (336) & & 2 & & 369.70 \\
\hline Primary Metal Manufacturing (331) & & & \\
\hline $\begin{array}{l}\text { Household Appliances \& Other Electrical } \\
\text { Equipment (335) }\end{array}$ & & & & \\
\hline
\end{tabular}

Source: own calculation based on DealWatch

Chinese multinationals are mostly active in large countries offering either natural resources or technology (Table 2). Top destinations of Chinese firms are located in the Asia-Pacific region. The desire for resources for their fast developing economy is the major reason for foreign acquisitions by Chinese firms. This result supports previous findings on outward FDI from China (Kolstad et al. 2012). Besides industries responsible for providing natural resources, technologically intensive businesses play a significant role. 
Acquiring American firms may be a valuable source of sophisticated technology and managerial expertise for further development. Such a pursuit does not always meet the acceptance of the host countries' governments. For example, the Chinese telecommunication giant Huawei had to withdraw its offer of acquisition of US technology firms due to the security concerns of American authorities.

Table 2

Cross-border M\&A deals by the key countries and industries (China)

\begin{tabular}{l|c|c|c|c|}
\hline Target countries and industries (NAICS 2007) & $\begin{array}{c}\text { Total } \\
\text { number }\end{array}$ & $\begin{array}{c}\text { By } \\
\text { industry }\end{array}$ & $\begin{array}{c}\text { Total } \\
\text { value } \\
\text { (USD m) }\end{array}$ & $\begin{array}{c}\text { By } \\
\text { industry } \\
\text { (USD m) }\end{array}$ \\
\hline United States & 53 & & 11290.50 & \\
\hline Professional, Scientific, and Technical Services (541) & & 6 & & NA \\
\hline Publishing Industries (except Internet) (511) & & 6 & & 7.00 \\
\hline Machinery Manufacturing (333) & & 5 & & 29.95 \\
\hline Transportation Equipment Manufacturing (336) & & 5 & & 583.33 \\
\hline Australia & 32 & & 19279.25 & \\
\hline Mining (except Oil and Gas) (212) & & 23 & & 7719.98 \\
\hline Oil and Gas Extraction (211) & & 5 & & 7275.33 \\
\hline Hong Kong & 30 & & 3794.35 & \\
\hline Broadcasting (except Internet) (515) & & 4 & & 478.73 \\
\hline Utilities (221) & 18 & 3 & & NA \\
\hline Canada & & 11 & & 2900.42 \\
\hline Mining (except Oil and Gas) (212) & & 4 & & 7330.03 \\
\hline Oil and Gas Extraction (211) & 15 & & 12348.02 & \\
\hline Kazakhstan & & 15 & & 12348.02 \\
\hline Oil and Gas Extraction (211) & &
\end{tabular}

Source: own calculation based on DealWatch

The top five destinations for Indian firms are only advanced economies (Table 3). These transactions can be described as focusing to move activities up the value chain. More insights into the phenomena are provided by the industry pattern of foreign acquisitions. Except for the mining firms in Australia, all the remaining transactions represent advanced industries. The initial cost advantages of Indian business process outsourcing or pharmaceutical firms have evolved towards technological leadership. The two main motives for foreign acquisitions are proximity to customers in developed countries and access to frontier technology. The significance of advanced industries is confirmed by the over 30\% share of IT and pharmaceutical deals in the total value of Indian acquisitions in the United States in the analysed period. 
Russian firms are active in the industries of Russia's national advantages. Their vast natural resources help firms representing mining and primary metal manufacturing to gain strong positions on the international stage (Table 4). Besides the primary industries, financial services and professional services abroad are attracting a significant number of Russian firms.

Table 3

Cross-border M\&A deals by the key countries and industries (India)

\begin{tabular}{l|c|c|c|c}
\hline \multicolumn{1}{c|}{$\begin{array}{c}\text { Target countries and industries } \\
\text { (NAICS 2007) }\end{array}$} & $\begin{array}{c}\text { Total } \\
\text { number }\end{array}$ & $\begin{array}{c}\text { By } \\
\text { industry }\end{array}$ & $\begin{array}{c}\text { Total } \\
\text { value } \\
\text { (USD m) }\end{array}$ & $\begin{array}{c}\text { By } \\
\text { industry } \\
\text { (USD m) }\end{array}$ \\
\hline United States & 287 & & 19159.68 & \\
\hline Publishing Industries (except Internet) (511) & & 78 & & 1688.63 \\
\hline $\begin{array}{l}\text { Professional, Scientific, and Technical } \\
\text { Services (541) }\end{array}$ & & 56 & & 1985.19 \\
\hline Chemical Manufacturing (325) & 116 & 34 & & 2616.01 \\
\hline United Kingdom & & 19 & & 378.85 \\
\hline Publishing Industries (except Internet) (511) & & 19 & & 1226.43 \\
\hline $\begin{array}{l}\text { Professional, Scientific, and Technical } \\
\text { Services (541) }\end{array}$ & & 15 & & 398.62 \\
\hline Chemical Manufacturing (325) & & 11 & & 974.99 \\
\hline Germany & & 9 & & 125.86 \\
\hline Chemical Manufacturing (325) & 6 & & 1200.69 \\
\hline $\begin{array}{l}\text { Transportation Equipment Manufacturing } \\
\text { (336) }\end{array}$ & & & 900.18 & \\
\hline Machinery Manufacturing (333) & & 10 & & 114.25 \\
\hline Singapore & & & & 258.83 \\
\hline Publishing Industries (except Internet) (511) & & 4 & & 74.79 \\
\hline Chemical Manufacturing (325) & & & & \\
\hline $\begin{array}{l}\text { Heavy and Civil Engineering Construction } \\
\text { (237) }\end{array}$ & & & & \\
\hline Australia & & & & \\
\hline Mining (except Oil and Gas) (212) & & & & \\
\hline $\begin{array}{l}\text { Professional, Scientific, and Technical } \\
\text { Services (541) }\end{array}$ & & & & \\
\hline
\end{tabular}

Source: own calculation based on DealWatch

When observing the geographical pattern of expansion, a conclusion about the need of diversification can be drawn. The transactions directed to the United Kingdom or the United States may be also motivated by the higher quality of the institutions in the host countries compared to Russia.

The industry patterns presented above confirm the strong relationship between the foreign expansion of firms and national advantages. In most cases the expansion is combined with strategic planning on a national scale. 
Table 4

Cross-border M\&A deals by the key countries and industries (Russian Federation)

\begin{tabular}{l|r|r|r|r}
\hline \multicolumn{1}{c|}{$\begin{array}{c}\text { Target countries and industries } \\
\text { (NAICS 2007) }\end{array}$} & $\begin{array}{c}\text { Total } \\
\text { number }\end{array}$ & \multicolumn{1}{c|}{$\begin{array}{c}\text { By } \\
\text { industry }\end{array}$} & $\begin{array}{c}\text { Total } \\
\text { value } \\
\text { (USD m) }\end{array}$ & $\begin{array}{c}\text { By } \\
\text { industry } \\
\text { (USD m) }\end{array}$ \\
\hline Ukraine & 172 & & 11260.32 & \\
\hline $\begin{array}{l}\text { Professional, Scientific, and Technical Services } \\
\text { (541) }\end{array}$ & & 20 & & 213.56 \\
\hline Food Manufacturing (311) & & 11 & & 1308.47 \\
\hline Telecommunications (517) & 54 & & 13380.91 & \\
\hline United States & & 17 & & 8490.90 \\
\hline Primary Metal Manufacturing (331) & 5 & & 1235.01 \\
\hline Internet Publishing and Broadcasting (516) & 4 & & 2050.00 \\
\hline Mining (except Oil and Gas) (212) & 49 & 4 & & 107.10 \\
\hline Professional, Scientific, and Technical Services (541) & & 10 & & 1001.96 \\
\hline Kazakhstan & & 7 & & 4188.60 \\
\hline Mining (except Oil and Gas) (212) & & & 175.20 \\
\hline Oil and Gas Extraction (211) & & 7 & & \\
\hline $\begin{array}{l}\text { Commercial Banking \& Other Credit } \\
\text { Intermediation Activities (522) }\end{array}$ & & & 1304.59 & \\
\hline United Kingdom & & & \\
\hline Performing Arts, Spectator Sports, and Related & & 5 & & 66.25 \\
\hline Industries (711) & & 5 & & 80.20 \\
\hline Primary Metal Manufacturing (331) & & & & 15.07 \\
\hline $\begin{array}{l}\text { Computer and Electronic Product Manufacturing } \\
\text { (334) }\end{array}$ & & 5 & & 1422.86 \\
\hline Administrative and Support Services (561) & & & & 344.27 \\
\hline Germany & & & & \\
\hline Chemical Manufacturing (325) & & & & \\
\hline Water Transportation (483) & & & & \\
\hline
\end{tabular}

Source: own calculation based on DealWatch

The industries with the highest numbers of deals are usually prone to international activities. The world's largest corporations are representatives of the oil, finance, car and computer industries. The same pattern can be also applied to the emerging multinationals. Vast internal markets provide the optimal base for global consolidation.

\section{ESTIMATION PROCEDURE}

The multiple linear regression analysis was applied to define the relationship between the number of mergers and acquisitions and explanatory variables. In this method explanatory variables (known) are used to predict the dependent variable (unknown). The rationale for using this econometric method was the characteristics of available data. A similar 
econometric technique was applied to estimating the geographic distribution of US multinationals (Sampayo 2006). However, in many previous contributions a probit or logit analysis was applied in order to assess the probability/odds of choosing one location over another (Chen et al. 2011).

The model takes the following linear form:

$$
\ln Y_{i}=\beta_{0}+\beta_{1} \text { border }_{i}+\beta_{\mathbf{2}} \text { distance }_{i}+\beta_{3} \text { arable }_{i}+\beta_{\mathbf{4}} \text { ease }_{i}
$$

where $Y_{i}$ is the number of cross-border merger and acquisition deals in country $i ; \beta_{\mathbf{0}}$ is constant and $\beta_{\mathbf{1}}-\beta_{\mathbf{g}}$ are coefficients; $\varepsilon_{i}$ is the standard disturbance term. The logarithmic transformation of the dependent variable was conducted in order to improve its fitting to the model.

The explained variable is the number of transactions in each host country undertaken by firms from the BRIC economies. The rationale behind choosing the explanatory variables was based on a multidimensional analysis. The predictor variables can be divided into the three following groups. The first group containing border, distance and arable can be labelled as geographical. The second group represents the investment climate and includes ease, legal and export_cost. The last group is composed of economic factors such as $g d p$ and $g d p \_$growth. When conducting the

Table 5

Explanatory variables

\begin{tabular}{|c|c|}
\hline Variable & Description and source \\
\hline Border & Dummy variable that takes 1 if common border and 0 otherwise \\
\hline Distance & $\begin{array}{l}\text { Distance in kilometres between home and host country capital cities } \\
\text { calculated using www.mapcrow.info }\end{array}$ \\
\hline Arable & $\begin{array}{l}\text { Arable land (unit: } 1000 \text { hectares); period: 2008; source: World } \\
\text { Development Indicators \& Global Development Finance }\end{array}$ \\
\hline Ease & $\begin{array}{l}\text { Ease of doing business index; a higher position in the rank indicates more } \\
\text { favourable business conditions; period: 2008; source: World Development } \\
\text { Indicators \& Global Development Finance }\end{array}$ \\
\hline export_cost & $\begin{array}{l}\text { Measures the fees levied on a 20-foot container in US dollars, period: 2008, } \\
\text { source: World Development Indicators \& Global Development Finance }\end{array}$ \\
\hline Legal & $\begin{array}{l}\text { Strength of legal rights index }(0=\text { weak to } 10=\text { strong); period 2008, source: } \\
\text { World Development Indicators \& Global Development Finance }\end{array}$ \\
\hline Gdp & $\begin{array}{l}\text { Gross domestic product at current prices (unit: } 1 \text { billion USD), period 2008, } \\
\text { source: World Development Indicators \& Global Development Finance }\end{array}$ \\
\hline gdp_growth & $\begin{array}{l}\text { Real gross domestic product growth in } \% \text { as arithmetic mean for years } \\
\text { 2008-2010, source: World Development Indicators \& Global Development } \\
\text { Finance }\end{array}$ \\
\hline
\end{tabular}

Source: author's own elaboration 
analysis, other factors were taken into consideration, but the requirements of the linear regression forced them to be removed from the analysis.

The first variable border is supposed to indicate the importance of a common border between the home and host countries. The emerging countries, which are under scrutiny in this paper, possess vast territories and thus many neighbours. However, the political relations with them may be strained. In many cases the diplomatic relations with neighbours may be described as "emerging". In the case of Brazil, the largest number of deals (61) was directed to Argentina. Venezuela, on the other hand, attracted a much lower number - three. The variable border has to be analysed with caution due to the fact that large territories are surrounded by neighbours of very different characteristics. For example, the Russian Federation borders both the European Union and Uzbekistan.

Together with the variable border comes the variable distance. The calculation may not perfectly present the distance between companies in two countries due to the fact that it measures the distance between capitals, not between the home and host towns or cities. The idea of calculating the distance between the countries engaged in investment should be also used to define the characteristics of multinational corporations: are they of a regional or global type? It is assumed that most operations are agglomerated in the nearest countries.

The variable arable was introduced to the analysis due to the fact that many multinational corporations from emerging countries are working in traditional industries. Therefore it is reasonable to include the measure indicating size of arable land. This variable can be also treated as a proxy for natural resources abundance. Large areas of such land come together with other mineral resources.

The above presented factors are out of the control of both business entities and governmental bodies. But the next group covering factors facilitating or decreasing the costs of running a business firm, are mostly dependant on government policies. The variable ease is the Ease of doing business index by the World Bank. This indicator, covering almost all countries in the world, is a universal measure of the business climate in a country. Among others, it measures the level of bureaucracy, financial environment quality and taxation system.

The variable export_cost represents the costs of running foreign trade from the host country. It is extremely important when the acquisition of a foreign firm is undertaken in order to supply other markets (export platform) or to send the goods to the home country. This is the case when FDI is undertaken to obtain some resources in the host country (iron ore extracted by Chinese companies in Africa is designated for the steel industry in China). 
The variable legal measures the quality of law in the host country. In the case of firms from emerging countries where the institutional quality is not of very high level, it is expected that they will expand to the countries of similar or lower legal standards.

The remaining two variables were employed to present the economic dimensions of the host economy. Its size, measured by GDP value, should be positively associated with the number of deals flowing into the economy. Moreover, FDI should be undertaken in markets with strong prospects for growth. Therefore the measure of expected dynamics of GDP should be applied as an indicator of future market potential.

The values for all analyses were dated 2008, except for the GDP growth rate, which was the mean of the period 2008-2010. The selection of the period is justified by the largest numbers of such deals in 2007 and 2008. FDI is the long term engagement of a firm in a foreign country. The prospects of the future situation are more important than the past, therefore the indicators looked forward instead of using time lags.

\section{ESTIMATION RESULTS}

The econometric model introduced in the preceding section was estimated separately for each economy. It is very important to note that the dependent variable was log-transformed which induced the low level of coefficients. The log-transformation was necessary to meet the requirements of linearity of the model.

It was a challenging task to prepare a model that would be useful to explain the flows of M\&A from the four emerging countries. The countries were very different and it was difficult to apply one universal model. However, some clear conclusions can be drawn from the data.

The coefficient for border was positive in three instances and statistically significant (Table 6). It confirms that EMNCs mostly expand to the neighbouring countries thus creating regional multinationals. The coefficient was negative for India, but also insignificant. The same situation occurred with other geographical coefficients for this country. This may be explained by the fact that top destinations for Indian firms were not neighbouring countries. The value of the coefficient for India can be also explained by the tense political relations with its neighbours. The same pattern can be applied to the development of trade between India and its neighbouring countries, where only a small percentage of trade is generated.

The coefficient for distance was negatively correlated with the number of M\&A projects for Brazil and Russia. This confirms the importance of 
proximity to foreign markets. The last geographical variable arable was significant only for Brazil, which is associated with the fact that the food industry represents the second most important industry investing abroad.

Firms from emerging countries choose locations with a favourable business climate as indicated by the estimation of the variable ease. For countries with the coefficient, statistically significant negative values appeared. The construction of the variable was that a smaller value denotes more promising business conditions. It can be interpreted that firms from emerging countries prefer locations with better quality of institutions, even if their countries of origin cannot be role models in this aspect. A similar situation occurred with the variable legal, which was positive, thus reflecting destinations where legal compliance is more common. Nevertheless, some deals were directed to the countries where only firms with lower legal standards dared to start operations, for example, Angola.

The coefficient for the economic variable $g d p$ was expected to indicate the impact of size of the host market on the number of investment projects in

Table 6

Estimation results

\begin{tabular}{l|c|c|c|c}
\hline $\begin{array}{c}\text { Dependent } \\
\text { variable }\end{array}$ & Brazil & China & India & $\begin{array}{c}\text { Russian } \\
\text { Federation }\end{array}$ \\
\hline Border & $1.037122^{* *}$ & $1.013867^{* *}$ & -.1535616 & $.6897372^{* *}$ \\
& $(.4887289)$ & $(.4251197)$ & $(.4885592)$ & $(.3067669)$ \\
\hline Distance & $-.0001358^{* * *}$ & 0,00000208 & -.0000253 & $-.0001017^{* * *}$ \\
& $(.0000423)$ & $(.0000284)$ & $(.0000253)$ & $(.0000372)$ \\
\hline Arable & $.0148446 * * *$ & .0037656 & .007722 & .0089118 \\
& $(.0050458)$ & $(.0050223)$ & $(.0057553)$ & $(.0062141)$ \\
\hline Ease & $-.0152768^{* * *}$ & $-.0092837 * *$ & $-.0048533^{*}$ & -.001681 \\
& $(.0046666)$ & $(.0037006)$ & $(.0025506)$ & $(.0029005)$ \\
\hline export_cost & -.0000156 & -.0000552 & -.0000839 & $.0005315^{* * *}$ \\
& $(.0004364)$ & $(.0001836)$ & $(.0001324)$ & $(.0001644)$ \\
\hline Legal & -.1264266 & -.0267651 & $.0982124 * *$ & $.0983011^{*}$ \\
& $(.0786966)$ & $(.0630923)$ & $(.0982124)$ & $(.0501685)$ \\
\hline Gdp & -.0000325 & $.0002427^{* * *}$ & $.0002977 * * *$ & .0001378 \\
& $(.0000795)$ & $(.0000816)$ & $(.0000872)$ & $(.0000976)$ \\
\hline gdp_growth & .0337797 & .072702 & -.0047981 & $-.0862686^{*}$ \\
& $(.0730838)$ & $(.0460093)$ & $(.0323935)$ & $(.040672)$ \\
\hline Cons & 3.297468 & 1.290526 & 1.066306 & .6959259 \\
& $(.8316525)$ & $(.6301369)$ & $(.3859647)$ & $(.4783159)$ \\
\hline adj. R2 & 0.5460 & 0.4335 & 0.5008 & 0.4321 \\
\hline obs. & 37 & 58 & 93 & 76 \\
\hline
\end{tabular}

Note: standard errors in parentheses; $*, * *, * *$ represent statistical significance at 0.1 , $0.05,0.01$ level respectively

Source: author's own elaboration 
this economy. However, in the cases of Brazil and Russia such regularity cannot be found. More compelling is the conclusion of the strong influence of the size of the host markets in the cases of India and China, at the same time there was no relation with the distance for the two countries. This means that firms from India and China prefer further destinations, but of a larger size. The growth rate of the host economies was not an important factor in the decision process of investment. Only the Russian Federation indicated the statistically significant relation, however the signs were not as expected. This can be interpreted as a result of targeting mostly established economies with very moderate growth. During the recent economic downturn many advanced economies experienced deep recession making some firms from these countries vulnerable targets.

Post-estimation tests were applied to check for homoscedasticity of residuals. The results of White's test indicated that the issue of heteroscedasticity was not a concern. Normality of residuals was necessary to confirm the validity of hypothesis testing. The method used to evaluate the normality of residuals was the Shapiro-Wilk test. The p-values obtained in the tests indicated that the hypothesis of normally distributed residuals could not be rejected.

The collinearity issue was evaluated using the variance inflation factor (VIF). For any of the analysed countries, VIF did not approach the value 10, which when exceeded is considered to be an indicator of a high linear relationship between predictors (Table 7).

Table 7

Results for variance inflation factor (VIF)

\begin{tabular}{l|l|l|l|l|l|l|l}
\hline \multicolumn{2}{c|}{ Brazil } & \multicolumn{3}{c|}{ China } & \multicolumn{2}{c}{ India } & \multicolumn{2}{c}{ Russia } \\
\hline Variable & VIF & Variable & VIF & Variable & VIF & Variable VIF & 1/VIF \\
\hline Ease & 3.51 & Ease & 3.19 & gdp & 2.71 & arable & 2.83 \\
\hline Arable & 3.01 & Arable & 2.38 & arable & 2.55 & gdp & 2.68 \\
\hline gdp_growth & 2.76 & Gdp & 2.28 & ease & 2.35 & ease & 2.05 \\
\hline Gdp & 2.61 & Legal & 2.09 & export_cost & 1.46 & gdp_growth & 1.64 \\
\hline Border & 2.40 & gdp_growth & 1.69 & legal & 1.44 & legal & 1.50 \\
\hline Legal & 2.23 & Border & 1.61 & gdp_growth & 1.37 & distance & 1.32 \\
\hline Distance & 2.14 & export_cost & 1.44 & border & 1.23 & export_cost & 1.32 \\
\hline export_cost & 2.07 & Distance & 1.23 & distance & 1.12 & border & 1.18 \\
\hline Mean VIF & $\mathbf{2 . 5 9}$ & Mean VIF & $\mathbf{1 . 9 9}$ & Mean VIF & $\mathbf{1 . 7 8}$ & Mean VIF & $\mathbf{1 . 8 1}$ \\
\hline
\end{tabular}

Source: author's own elaboration

Additional confirmation of the lack of severe multicollinearity is presented in correlation matrixes in appendix Tables 1A-4A. 


\section{CONCLUSIONS}

This paper was aimed at defining the key factors that influence the decision of foreign investment location by firms from emerging countries. Using data on the geographical distribution of the expansion of enterprises from the BRIC countries, the importance of factors in decision making on foreign engagement was estimated.

The most important conclusion is that location factors play a very important role in merger and acquisition deals. Econometric tests confirmed the significance of the host countries' characteristics. Thus the key research hypothesis was positively verified. There is a great differentiation in the results between the business entities from each of the four countries. This is partly explained by the industry structure.

A location decision may be also highly associated with political reasons. Tense diplomatic relations pose problems for investing firms, especially if we take into consideration the fact that many EMNCs are controlled by home governments.

Relating the obtained results to other empirical contributions, but covering the expansion of multinational corporations from developed countries, we can notice the significant role of geographical factors compared to the group of economic determinants.

Multinationals from emerging countries are mostly perceived as resourceful and determined companies aiming at obtaining control over firms from developed countries. It was important to investigate if firms from the BRIC countries exploit investment opportunities within the group. Based on the results, we can conclude that other BRIC countries are in a distant position as preferable investment locations. This is interesting especially when the qualities of the counterparts are taken into consideration (large and fast growing economies, vast territories, natural resources).

Future work on the topic should also include the industry and firm-level controls of the location decision. Due to the unavailability of relevant data for a more detailed analysis, this paper was the first step in developing further research.

\section{REFERENCES}

Basile, R., Castellani, D., Zanfei, A., Location Choices of Multinational Firms in Europe: The Role of EU Cohesion Policy, "Journal of International Economics", 74(2), pp. 328-340, 2008.

Chen, M.-Y., Chang J.-Y., The Choice of Foreign Market Entry Mode: An Analysis of the Dynamic Probit Model, "Economic Modelling", 28(1-2), pp. 439-450, 2011. 
Cheng, L. - Kwan Y., What Are the Determinants of the Location of Foreign Direct Investment? The Chinese Experience, "Journal of International Economics", 41(2), pp. 379-400, 2000.

Dunning, J., Location and Multinational Enterprise: A Neglected Factor?, "Journal of International Business Studies”, 29(1), pp. 45-66, 1998.

Flores, R., Aguilera, R., Globalization and Location Choice: An Analysis of US Multinational Firms in 1980 and 2000, "Journal of International Business Studies", 38(7), pp. 1187$-1210,2007$.

Grossman, G., Helpman, E., Szeidl, A., Optimal Integration Strategies for the Multinational Firm, "Journal of International Economics", 70(1), pp. 216-238, 2006.

Head, K., Ries, J., Swenson, D., Agglomeration Benefits and Location Choice: Evidence from Japanese Manufacturing Investments in the United States, "Journal of International Economics", 38(3-4), pp. 223-247, 1996.

Klimek, A., Emergence of Multinational Firms from Middle Income Countries: The Case of Poland, "Argumenta Oeconomica", 26(1), pp. 91-110, 2011.

Klimek, A., Cross-border Mergers and Acquisitions as a Form of Expansion of Multinational Corporations from the BRIC Countries [in:] Skulska, B., Domiter, M., Michalczyk, W. (eds.), Globalisation and regionalisation in the world economy, pp. 414-424. Wroclaw University of Economics Publishing House, Wroclaw 2012.

Kolstad, I., Wiig, A., What Determines Chinese outward FDI?, "Journal of World Business", 47(1), pp. 26-34, 2012.

Ragozzino, R., The Effects of Geographic Distance on the Foreign Acquisition Activity of U.S. Firms, "Management International Review", 49(4), pp. 509-535, 2009.

Reuer, J., Koza, M., Asymmetric Information and Joint Venture Performance: Theory and Evidence for Domestic and International Joint Ventures, "Strategic Management Journal", 21(1), pp. 81-88, 2000.

Rivera-Batiz, L., Oliva, M., International Trade. Theory, Strategies, and Evidence. Oxford: Oxford University Press, 2003.

Rugman, A., The Regional Multinationals. MNEs and 'Global' Strategic Management. Cambridge: Cambridge University Press, 2005.

Sampayo, F., The Geographic Distribution of Economic Activities of the USA Multinational Enterprises. DEGIT Conference Papers, C011_040, 2006.

UNCTAD Cross-border M\&A database, www.unctad.org/fdistatistics, accessed [10-02-2012].

Received: May 2013, revised: May 2016

Acknowledgments: The project has been financed by the National Science Centre according to the decision no. DEC-2011/01/D/HS4/01204. The author also acknowledges the financial support of the Foundation for Polish Science.

An earlier version of the paper was presented at the XIII Conference on International Economics, Granada, 21-22 June 2012. 
Table 1A

Summary statistics for Brazil

\begin{tabular}{l|c|c|c|c|c|c|c|c|c|c|c|c}
\hline \multicolumn{1}{c|}{ Variable } & Obs. & Mean & Std. Dev. & no & border & distance & arable & ease & export_cost & legal & gdp & gdp_growth \\
\hline no & 37 & .9830149 & 1.115949 & 1.0000 & & & & & & & & \\
\hline border & 37 & .1891892 & .3970613 & 0.5335 & 1.0000 & & & & & & & \\
\hline distance & 37 & 7861.054 & 4326.056 & -0.4283 & -0.6196 & 1.0000 & & & & & & \\
\hline arable & 37 & 22.44349 & 43.09465 & 0.1830 & -0.1752 & 0.4113 & 1.0000 & & & & & \\
\hline ease & 37 & 71.78378 & 50.28758 & -0.1323 & 0.3151 & -0.3587 & 0.0156 & 1.0000 & & & & \\
\hline export_cost & 37 & 1201.243 & 412.8617 & 0.0568 & 0.3645 & -0.3664 & -0.0651 & 0.4669 & 1.0000 & & & \\
\hline legal & 37 & 5.459459 & 2.375741 & -0.0857 & -0.3892 & 0.4247 & 0.2605 & -0.6478 & -0.3045 & 1.0000 & & \\
\hline gdp & 37 & 1298.412 & 2545.902 & 0.1681 & -0.2202 & 0.3391 & 0.6311 & -0.3759 & -0.2232 & 0.3756 & 1.0000 & \\
\hline gdp_growth & 37 & 2.121739 & 2.851258 & 0.2120 & 0.4239 & -0.2140 & 0.2114 & 0.4921 & -0.0543 & -0.2147 & -0.2166 & 1.0000 \\
\hline
\end{tabular}

Source: author's own elaboration

Table 2A

Summary statistics for China

\begin{tabular}{|c|c|c|c|c|c|c|c|c|c|c|c|c|}
\hline Variable & Obs. & Mean & Std. Dev. & no & border & distance & arable & ease & export_cost & legal & gdp & gdp_growth \\
\hline no & 58 & 1.007575 & 1.104446 & 1.0000 & & & & & & & & \\
\hline border & 58 & .1206897 & .3286114 & 0.2691 & 1.0000 & & & & & & & \\
\hline distance & 58 & 8683.31 & 4290.871 & -0.1826 & -0.3245 & 1.0000 & & & & & & \\
\hline arable & 58 & 16.31566 & 33.84171 & 0.4549 & 0.3100 & -0.0385 & 1.0000 & & & & & \\
\hline ease & 58 & 68.7931 & 53.17457 & -0.3727 & 0.1511 & 0.2091 & 0.0782 & 1.0000 & & & & \\
\hline export_cost & 58 & 1309.586 & 719.4455 & -0.1012 & 0.3110 & -0.0352 & -0.0453 & 0.4107 & 1.0000 & & & \\
\hline legal & 58 & 6.086207 & 2.522074 & 0.2981 & 0.0084 & -0.1597 & 0.0616 & -0.6792 & -0.3298 & 1.0000 & & \\
\hline gdp & 58 & 845.3122 & 2037.024 & 0.5571 & -0.0679 & -0.0139 & 0.6122 & -0.2758 & -0.1449 & 0.1856 & 1.0000 & \\
\hline gdp_growth & 58 & 2.530051 & 3.114506 & -0.1000 & 0.2140 & 0.0013 & 0.0457 & 0.5595 & 0.3641 & -0.2325 & -0.2813 & 1.0000 \\
\hline
\end{tabular}

Source: author's own elaboration 
Table 3A

Summary statistics for India

\begin{tabular}{l|c|c|c|c|c|c|c|c|c|c|c|c}
\hline \multicolumn{1}{c|}{ Variable } & Obs. & Mean & Std. Dev. & no & border & distance & arable & ease & export_cost & legal & gdp & gdp_growth \\
\hline no & 93 & 1.225273 & 1.219192 & 1.0000 & & & & & & & & \\
\hline border & 93 & .0430108 & .203981 & 0.0321 & 1.0000 & & & & & & & \\
\hline distance & 93 & 6704.581 & 3760.136 & -0.0418 & -0.2515 & 1.0000 & & & & & & \\
\hline arable & 93 & 10.90844 & 24.94157 & 0.4665 & 0.1626 & 0.1185 & 1.0000 & & & & & \\
\hline ease & 93 & 74.66667 & 53.99201 & -0.4757 & 0.1128 & 0.0883 & -0.0052 & 1.0000 & & & & \\
\hline export_cost & 93 & 1284.075 & 818.4832 & -0.2775 & -0.0841 & 0.1108 & -0.0040 & 0.5303 & 1.0000 & & & \\
\hline legal & 93 & 5.591398 & 2.567508 & 0.4287 & 0.0339 & -0.0577 & 0.0572 & -0.5351 & -0.2228 & 1.0000 & & \\
\hline gdp & 93 & 619.7349 & 1696.101 & 0.6241 & 0.0684 & 0.1142 & 0.7466 & -0.2510 & -0.1253 & 0.1900 & 1.0000 & \\
\hline gdp_growth & 93 & 2.673838 & 3.247325 & -0.2398 & 0.2608 & -0.0601 & 0.0293 & 0.4494 & 0.1698 & -0.2278 & -0.1845 & 1.0000 \\
\hline
\end{tabular}

Source: author's own elaboration

Table 4A

Summary statistics for Russian Federation

\begin{tabular}{l|c|c|c|c|c|c|c|c|c|c|c|c}
\hline \multicolumn{1}{c|}{ Variable } & Obs. & Mean & Std. Dev. & no & border & distance & arable & ease & export_cost & legal & gdp & gdp_growth \\
\hline no & 76 & 1.604861 & 1.230133 & 1.0000 & & & & & & & & \\
\hline border & 76 & .1710526 & .379057 & 0.3486 & 1.0000 & & & & & & & \\
\hline distance & 76 & 4041.289 & 3308.495 & -0.3566 & -0.3022 & 1.0000 & & & & & \\
\hline arable & 76 & 11.2055 & 28.99164 & 0.2765 & 0.0561 & 0.1791 & 1.0000 & & & & & \\
\hline ease & 76 & 69.21053 & 52.80664 & -0.2430 & -0.1237 & 0.0841 & 0.0173 & 1.0000 & & & & \\
\hline export_cost & 76 & 1284.921 & 747.4942 & 0.1506 & 0.0512 & -0.0444 & -0.0910 & 0.4256 & 1.0000 & & & \\
\hline legal & 76 & 6.236842 & 2.612118 & 0.2714 & 0.0259 & 0.0993 & 0.1648 & -0.5064 & -0.2310 & 1.0000 & & \\
\hline gdp & 76 & 608.4258 & 1794.788 & 0.3394 & -0.0313 & 0.1088 & 0.7248 & -0.2238 & -0.1308 & 0.1511 & 1.0000 & \\
\hline gdp_growth & 76 & 1.873514 & 3.372226 & -0.3042 & -0.0723 & 0.3330 & 0.1945 & 0.4730 & 0.3006 & -0.2428 & -0.0717 & 1.0000 \\
\hline
\end{tabular}

Source: author's own elaboration 